Chan Hing-ho, Joyce Liu Chi-hui, Peng Hsiao-yen, Angel Pino, and Isabelle Rabut (eds.), La littérature taïwanaise. État des recherches et réception à l'étranger Paris, You Feng, 2011, 680 pp.

\title{
Gwennaël Gaffric
}

Translator. N. Jayaram

\section{OpenEdition}

\section{Journals}

Electronic version

URL: http://journals.openedition.org/chinaperspectives/5910

DOI: 10.4000/chinaperspectives.5910

ISSN: 1996-4617

\section{Publisher}

Centre d'étude français sur la Chine contemporaine

\section{Printed version}

Date of publication: 4 June 2012

Number of pages: 95-96

ISSN: 2070-3449

\section{Electronic reference}

Gwennaël Gaffric, « Chan Hing-ho, Joyce Liu Chi-hui, Peng Hsiao-yen, Angel Pino, and Isabelle Rabut (eds.), La littérature taïwanaise. État des recherches et réception à l'étranger », China Perspectives [Online], 2012/2 | 2012, Online since 30 June 2012, connection on 22 September 2020. URL : http:// journals.openedition.org/chinaperspectives/5910; DOI : https://doi.org/10.4000/chinaperspectives. 5910

This text was automatically generated on 22 September 2020

(c) All rights reserved 


\section{Chan Hing-ho, Joyce Liu Chi-hui, Peng Hsiao-yen, Angel Pino, and Isabelle Rabut (eds.), La littérature taïwanaise. État des recherches et réception à l'étranger}

Paris, You Feng, 2011, 680 pp.

\section{Gwennaël Gaffric}

Translation : N. Jayaram

1 This work brings together the quasitotality of proceedings at a 2004 colloquium in Bordeaux. Contributions in English and Chinese were translated into French by Hervé Denès, Angel Pino, and Isabelle Rabut.

2 After an introduction by Pino and Rabut, the book contains three parts, the first two presenting original studies on Taiwanese literature and analyses of translations and their reception in Britain, Germany, the United States, and France, and the third being a vast bibliography of more than 300 pages shedding light on academic works and translations on Taiwanese literature in German, English, and French up to 2005.

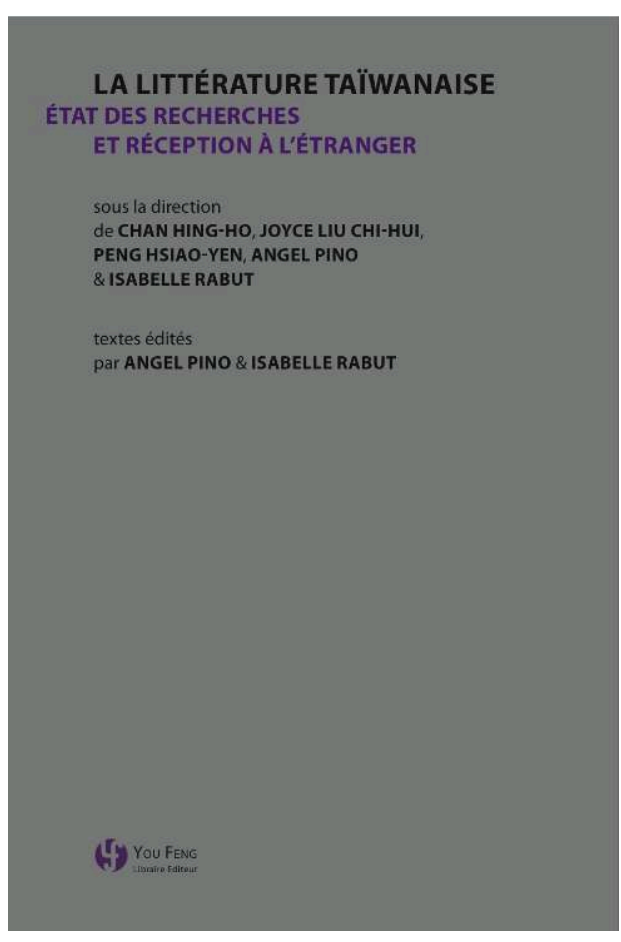

LA LITTERATURE TAIWANAISE

ET RÉCEPTION Á L'ÉTRANGER

sous la direction

textes édités

par ANGEL. PINO \& ISABELLE RABUT 
of Taiwan's literary modernism between the 1950s and 1990s. Contributions by Chen Fang-ming, Chiu Kuei-fen, and Zhang Yinde focus on the issue of readings of works and Western modernism theories in Taiwanese literary circles. They refute the idea of a simple "Taiwanese imitation" or one-sided Western imperialist influence, highlighting the ambiguity and creativity of the island's authors in their retranslations, appropriations, and inter-textual reconstructions.

In Chapter 2, "History of the literature," the contributions of Lin Juei-ming and Li Xiangping complement each other: they explore the ways in which the history of Taiwanese literature is written by presenting diametrically different viewpoints. While Lin Juei-ming seeks to retrace the contours of what he calls "Taiwaneseness" by stressing the particularities of the history of literary criticism in Taiwan, Li Xiangping offers a more sinocentric critique of what he deems nationalist romanticism of a certain literary historiography on the island. He emphasises the traumatisms of the Japanese era (which as far as he's concerned function as common stigma in Taiwanese and Chinese histories). Sandwiched between these two contributions is that of Chen Wan-yi, who discusses the work of writer Yang Kui, ${ }^{1}$ especially his early attempts at "literature in Taiwanese" at a time (in the island's literary circles in the 1930s) when the choice of language for writers was a major problematic.

5 In Chapter 3, "Literature and history," Peng Hsiao-yen shows the links between writing and memory among writers in garrison villages (juancun) ${ }^{2}$ such as Zhu Tianxin and Zhang Dachun. Joyce Liu Chi-hui analyses the feeling of decadence among some Taiwanese poets of the Japanese era, especially Yang Shichang (which would have been rendered as Yang Chichang in pinyin). Mei Chia-ling offers a study on the representation of the body in Taiwanese fiction in the Japanese era.

6 Chapter 4, "Some Taiwanese literary works," contains five contributions. Li Shershiueh compares Wandering in the Garden, Waking from a Dream by Bai Xianyong with Virginia Woolf's Mrs Dalloway. Pei-yin Lin invites rediscovery of an "alternative canon" in Wind and Moon, a periodical from the "Japanese occupation" era. Esther Lin offers a tour d'horizon of new writing strategies among the generation of Taiwanese writers born after the 1960s. Sandrine Marchand deals with the issue of memory in Wang Wenxing's Family Catastrophe,and finally, Lin Ming-teh dissects the influence of L'Affaire Crainquebille by Anatole France on Lai He's famous novel A 'Steelyard' (chengzi in pinyin, but it could also be rendered in Taiwanese as chhin-á in accordance with Lai He's original intentions).

7 In Part Two, the contributions of Pino, Rabut, Christina Neder, and Pei-yin Lin lay out in an interesting way the links between the strategies of translation and publication of Taiwanese literature and the island's visibility in the world.

8 From a simple point of view of organising the contributions, it might have been wiser to start with reflections on the way in which Taiwanese literature is written, instead of opening the collection with the issue of modernism. Similarly, arranging in chronological chapters would have avoided a situation in which studies on authors from the Japanese period (such as Lai He, Yang Kui, and Yang Chichang, or even the analyses of Pei-yin Lin and Mei Chia-ling) are far apart from each other. The editors could have also chosen to invite reflections on the analyses of Zhang Yinde and Li Shershiueh, as both of them offer a comparative study of the work of Bai Xianyong, and would thereby have avoided having the contribution of Esther Lin on the new 
generation of Taiwanese novelists sandwiched between a study of a periodical from the Japanese period and one of a novel (Family Catastrophe) from 1973.

Further, while it is important to accord the colossal bibliographical work of Pei-yin Lin (Britain), Christiane Hammer (Germany), and especially Pino (the United States and France) their due in Part Three of the book, it is regrettable that the list ends with 2005 in a 2011 publication: It is evident that, for instance, no fewer than 13 Taiwanese novels and anthologies of poems were translated and published in French in between, not to mention important recent academic contributions on the subject. ${ }^{3}$ It might have been interesting to include an assessment of the reception of Taiwanese literature in Japan, a major centre of Taiwan studies and a country where a large number of Taiwanese literary works have been translated. Meanwhile, a consideration of "aboriginal" literature in Chinese is surprisingly absent from this collection.

The book regrettably is not without some misprints. Finally, apart from the useful inclusion of translators' notes, it would have been interesting - albeit at the risk of adding to their work - if some information had been added regarding the terms used in the original contributions. For instance, what does "Taiwanese spoken language" stand for in Chen Wan-yi's article - Taiyu or Taiwan huawen? Is the "Chinese region of Taiwan" in Li Xiangping's text a translation of Taiwan qu or Taiwan sheng?

Despite some of these editorial lapses, the book is a remarkable effort at presenting the different ways in which Taiwanese literature is viewed abroad, by giving voice to scholars from different climes and divergent ideological viewpoints, thus offering a rich insight into the history of Taiwanese literature in different periods. Similarly, the bibliographic work in the last part constitutes, despite being incomplete, an inestimable resource for anyone interested in Taiwanese literature.

In their introduction, Pino and Rabut raise the question whether Taiwanese literature is a "branch" of Chinese literature or is completely independent (p.15). The transtextual details examined in this book and that of Marchand suggest the possibility of an alternative interpretation: Taiwanese literature being neither exclusively "sinoreferential" nor entirely "self-referential," would it not be possible to assert rather that it is Chinese literature that is a component of Taiwanese literature, in the same way as is Japanese literature or that of Virginia Woolf, James Joyce, and Anatole France, or more recently Milan Kundera, Haruki Murakami, and Gabriel Garcia Marquez?

The two books considered above, the first works in French exclusively concerned with Taiwanese literature - but in a way that is not entirely exclusive - bring out the rich particularities of Taiwanese poetics and can be expected to nurture more Francophone studies on the island's literature.

\section{NOTES}

1. Unlike in Sandrine Marchand's book, editors of this book chose to retranscribe authors' names in pinyin. The two books do contain parallel spellings in their index. 
2. Villages where families of soldiers who followed Chiang Kai-shek were housed.

3. Two recent articles (in Chinese) could partly bridge this gap: Zhuo Li (Esther Lin-Rosolato), "Taiwan wenxue zuopin fayi yu jieshou" (Translation and reception of Taiwanese literature in France), Taiwan wenxue guan tongxun (Bulletin of the National Museum of Taiwan Literature), no. 32, 09/2011, pp. 18-23; and Guan Shou-qi (Gwennaël Gaffric), "Taiwan wenxue zai faguo de xianzhuang" (Assessment of Taiwanese literature in France), Wenshi Taiwan xuebao (Academic journal on Taiwanese literature and history), no. 3, 12/2011, pp. 101-120.

\section{AUTHORS}

\section{GWENNAËL GAFFRIC}

Doctoral candidate at l'Institut d'études transtextuelles et transculturelles (IETT - Institute of Transtextual and Transcultural Studies) at the Jean Moulin Lyon 3 University, currently attached to the Institute of Taiwanese Literature at National Taiwan University. 